\title{
Assessment of Traffic Related Air Pollution and Ambient Air Quality of Metropolitan Cities (Case Study of Pune City)
}

\author{
Milind R. Gidde ${ }^{1}$ Pravin P.Sonawane ${ }^{2}$ \\ ${ }^{1}$ Department of Civil Engineering, Bharati Vidyapeeth University College of Engineering, Pune 43. \\ ${ }^{2}$ Institute of Environmental Education and Research, Bharati Vidyapeeth, Katraj Dhankawadi Pune 43.
}

\begin{abstract}
The rapid growth in motor vehicles activity in India and other rapidly industrializing low-income countries is contributing to high levels of urban air pollution, among other adverse socioeconomic, environmental, health, and welfare impacts. The purpose of the study was to investigate the relation between air quality and traffic with respect to Pune city from Jan 2008 to Dec 2011. Vehicle count and air quality was analyzed. Analytical and statistical method was applied. It was found that the strong correlation of increasing vehicles with nitrogen oxides (NOx), sulphur dioxide $\left(\mathrm{SO}_{2}\right)$ and suspended particulate matters (SPM). Study shows that there is tremendous growth in vehicles from 2008 to 2011. Particulate matter (PM10), NOx concentrations levels were exceeding standards. Study found that there is increase in $\mathrm{SO}_{2}$ concentration levels. Air quality correlation also analyzed with the fuel types and it was observed that petrol vehicles contribute more pollution than diesel.
\end{abstract}

Keywords: Air pollution, fuel, air quality, vehicle emissions.

\section{Introduction}

\section{Air Pollution:}

Air pollution has been aggravated by developments that typically occur as countries become industrialized: growing cities, increasing traffic, rapid economic development and industrialization, and higher levels of energy consumption. The high influx of population to urban areas, increase in consumption patterns and unplanned urban and industrial development has led to the problem of air pollution. Currently, in India, air pollution is widespread in urban areas where vehicles are the major contributors and in a few other areas with a high concentration of industries and thermal power plants. Vehicular emissions are of particular concern since these are ground level sources and thus have the maximum impact on the general population. Also, vehicles contribute significantly to the total air pollution load in many urban areas.

Air pollution in Pune city is an issue of very great concern today. In typical urban environment, air has other substance which in excess of certain proportions could be harmful to human health or vegetation. This could be called air pollution. The quality of air we breathe has deteriorated to a very large extent due to toxic substance like sulphur dioxide $\left(\mathrm{SO}_{2}\right)$, nitrogen oxide $(\mathrm{NOx})$, carbon monoxide $(\mathrm{CO})$ and particulate matter from many sources like industry, automobiles, power plants, air conditioning equipment etc. However, it is estimated that more than $60 \%$ of the air pollution is caused by automobile emissions.

Vehicular Pollution:

It is worth mentioning here that vehicular exhaust are obnoxious and occur at ground level. Vehicular pollution sources are not homogenous, as there is a complete range of technological mix. The mix could be in terms of fuel used - gasoline or diesel or natural gas; or engine type - 2-stroke or 4-stroke and/or a combination of these.

\section{Emissions from Gasoline Vehicles:}

Gasoline-powered engines are of two types: 4-stroke and 2-stroke. The exhaust emissions from gasoline-run vehicles consist of $\mathrm{CO}, \mathrm{HC}, \mathrm{NOx}, \mathrm{SO}_{2}$, and partial oxides of aldehydes, besides particulate matters including lead salts. The incomplete combustion of gasoline due to an imbalance in the air-fuel ratio leads to emissions of $\mathrm{CO}$ and $\mathrm{HC}$ especially from 2-stroke engines. The Nox, however, are formed due to high combustion temperature and availability of oxygen and nitrogen in the combustion chamber, whereas aldehydes result from the partial oxidation of HC. In cities, majority of the pollution is emitted by vehicles consuming gasoline - especially 2 and 3-wheelers, having predominantly 2-stroke engine. The 2-stroke 2 - and 3-wheelers require $2 \mathrm{~T}$ oil for lubrication of engine, which is carried out through either premixing mode or oil injection system. In either case it is a total loss system, as the oil is burnt along with the fuel. Since the burning quality of mineral based lubricating oil is very poor vis-à-vis gasoline, major fraction of it that enters the engine either remains unburned or burns only partially. This unburned and partially burned oil comes through the exhaust and is responsible for smoke and SPM emission. The studies indicate that 2-stroke engine's exhaust contains almost 

Pune City)

15-25\% of unburned fuel (Pundir, 2001). In actual practice, the 2 -stroke vehicles require $2 \%$ concentration of 2 $\mathrm{T}$ oil i.e., $20 \mathrm{ml}$ in a litre of petrol and even a modest $1 \%$ increase of oil, may lead to $15 \%$ increase in SPM besides visible smoke (CPCB, 1999).

\section{Emissions from Diesel Vehicles:}

As diesel engines breathe only air, blow by gases from the crankcase (consisting primarily of air and HC) are rather low. Due to its low volatility, evaporative emissions from the fuel tank can also be ignored. The low concentration of $\mathrm{CO}$ and un-burnt $\mathrm{HC}$ in the diesel exhaust are compensated by high concentration of NOx. Diesel engines also emit smoke particles and oxygenated HC, including aldehydes and odour-producing compounds having high nuisance value. Smoke from diesel engines comes in three different hues - white smoke emitted during cold start idling and at low loads; blue smoke from the burning of lubricating oil and additives; and black smoke, a product of incomplete combustion. Black smoke, the most obvious type of vehicular air pollution, consists of irregular shaped agglomerated fine soot/particulates, the formation of which depends on injector nozzle parameter and type of combustion chamber (direct or indirect injection). Black smoke is a particular problem with diesel engines that are not well tuned, which is often the case in the developing world.

Materials and MethodLiterature

A detailed study was carried out to collect baseline information related to various work done on the subject, methodology used and what were their observations. It includes review of books, journal, website, and magazines to understand the present status of work on traffic related air pollution and air quality and their relation. This step provided framework and basic knowledge for further research.

\section{Site Selection}

Two locations Swargate Junction and Karve Road were selected for the analysis of vehicle traffic. The selection site was based on factors like traffic density, pollution status and traffic congestion.

\section{Data Collection}

Secondary data was collected from RTO(Regional Transport office), MPCB(Maharashtra Pollution Control Board), PMC, ARAI.

\section{Data Analysis}

Vehicle count was taken from data and analyze to obtained percentage of vehicles. Total registered vehicle data was taken from data and analyze to obtained present vehicles. Air Quality is taken and analyze. Statistical methods were used for analyzing data.

\begin{tabular}{|l|l|}
\hline Value of "r" & Degree of Correlation \\
\hline${ }_{-}^{+} 0.7$ to 1 & High \\
\hline${ }_{-}^{+} 0.3$ to ${ }_{-}^{+} 0.7$ & Moderate \\
\hline 0 to ${ }_{-}^{+} 0.3$ & Low \\
\hline
\end{tabular}

\section{$\underline{\text { Result and Discussions }}$}

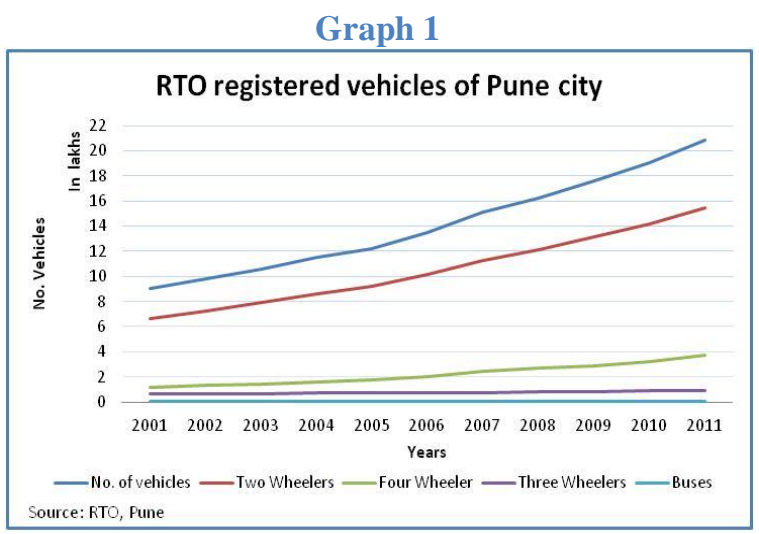

As seen during study Pune's vehicular population going on increasing at faster rate this is due to urbanization of Pune city. City is expanding at faster rate because of industrialization Pune is emerging as IT park city it provides a source of employment and also Pune is major corridor of education which attracts the people from other state migrating to urban areas. Another reason decreasing cost of vehicles (at affordable rate), different companies are also coming with vehicle loans 


\section{Graph 2}

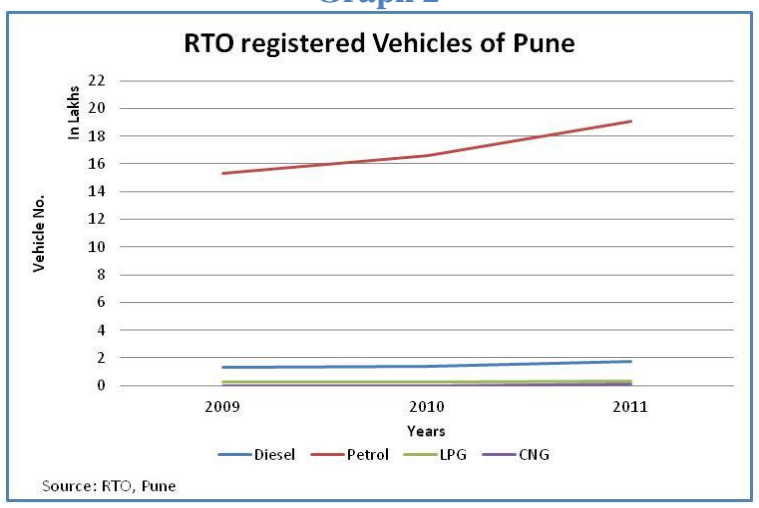

Graph 1 and Graph 2 shows trend of vehicular population. Two wheelers accounted $74 \%$ of total vehicular population while three wheelers 3\% and 17\% vehicle load is of four wheelers. Graph 4 shows RTO registered vehicles according to fuel category. This shows petrol vehicles contribute $91 \%$. This is due to decreasing cost of vehicles(at affordable rate), different companies are also coming with vehicle loans, due to rapid increase in urbanization in Pune it is emerging as a IT Park also which is providing a large employment and Pune is major corridor of Education which attracting people migrating to Pune.
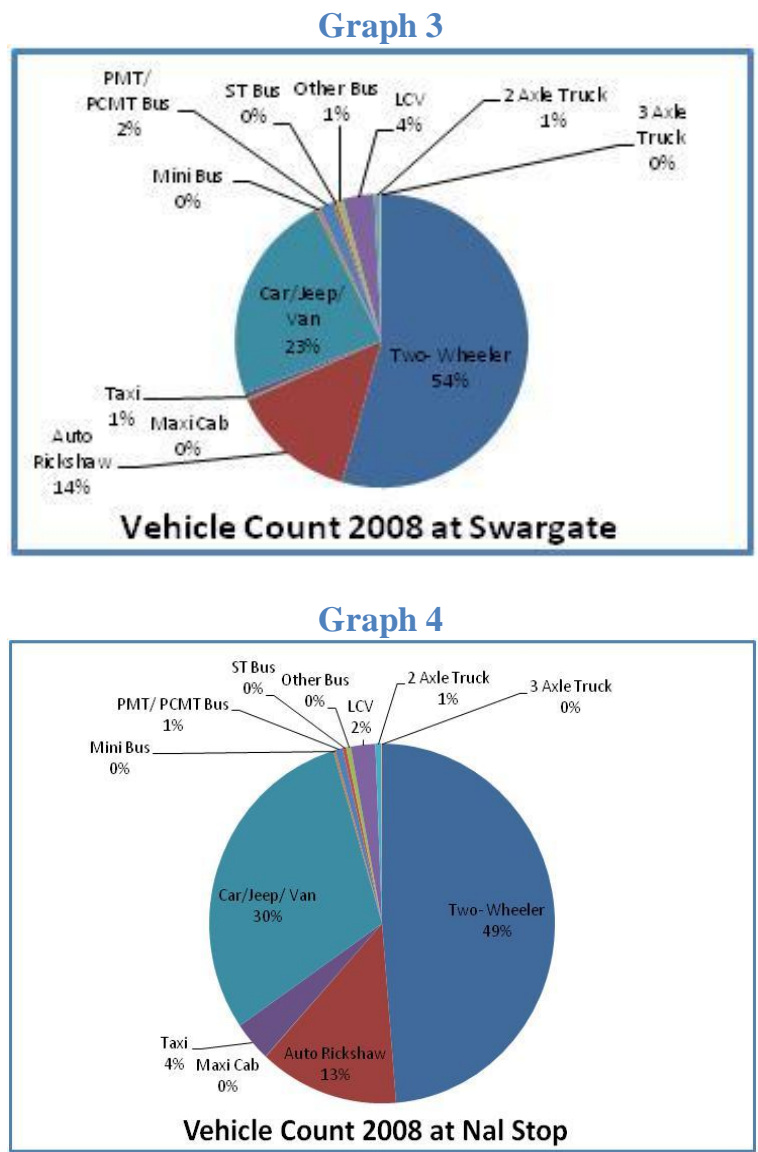

From traffic density Graph 3 and Graph 4 it is observed that at selected locations two wheelers count is around $50 \%$, Auto rickshaw is around $14 \%, 4$ Wheelers is $23-30 \%$, buses $1-3 \%$. The numbers of vehicles registered in 2008 were 16, 22,675. While in year 2011 reached to 20,88,093. The number of two wheelers has gained increase of $45 \%$ from 2008 to 2011. 
Assessment of Traffic Related Air Pollution and Ambient Air Quality of Metropolitan Cities (Case Study of $\underline{\text { Pune City) }}$

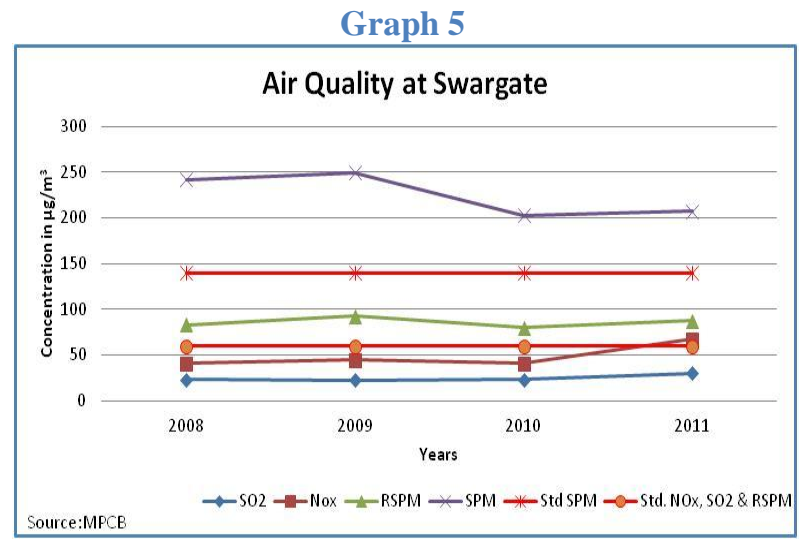

Graph 6

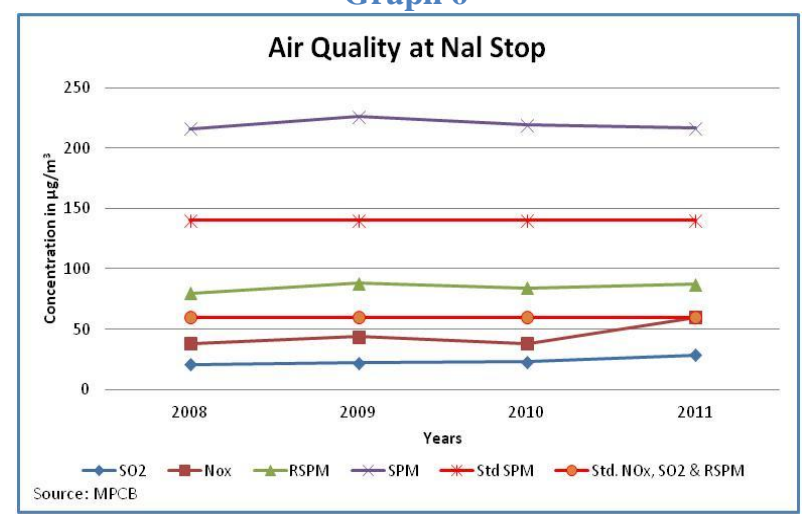

Graph 7

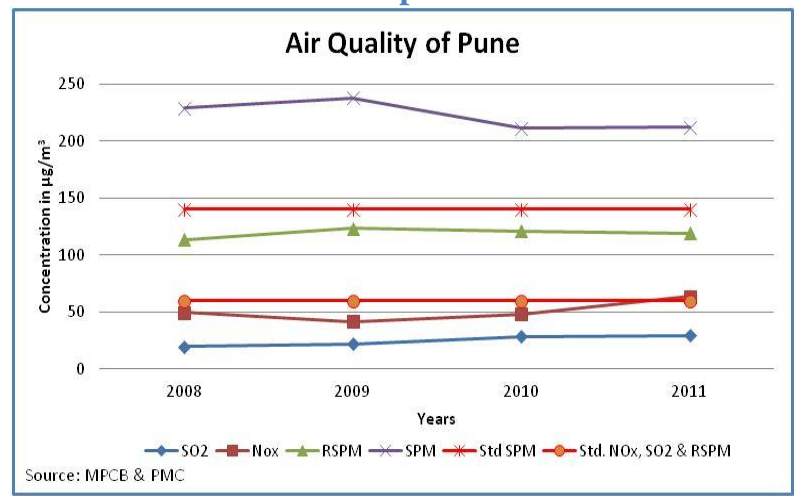

Air Quality of Swargate, Nal Stop and Pune was showed in Graph 5,6 and 7 shows that SPM and RSPM concentration levels at all the location are above the standard limit given by National Ambient Air Monitoring Standards (NAAQS) given by CPCB. NOx concentrations in 2011 were above limit given by NAAQS. $\mathrm{SO}_{2}$ concentration levels were observed to be within the limits.

Graph 8

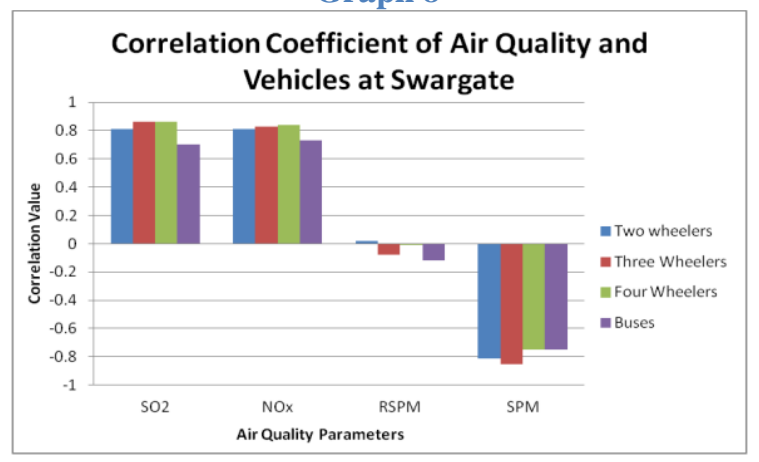




\section{Graph 9}

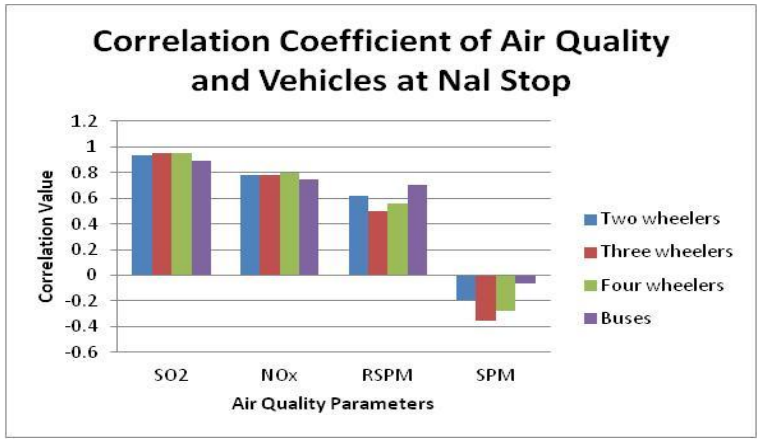

Graph 10

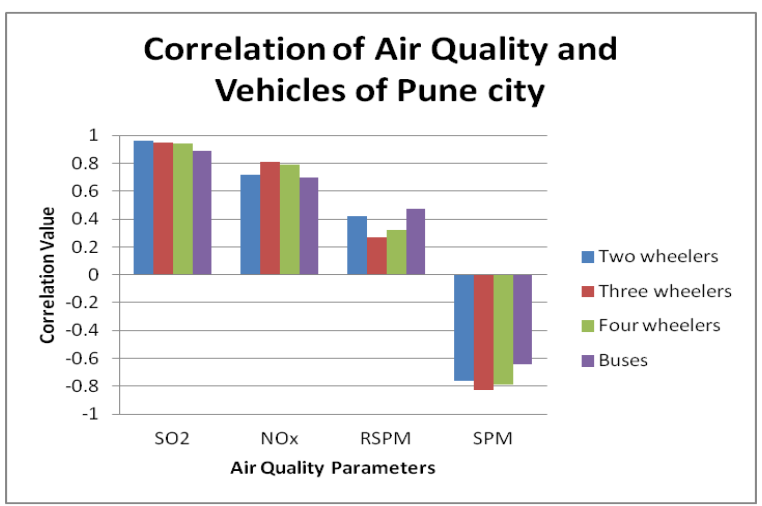

Air Quality and vehicles at Swargate, Nal Stop and Pune was taken under study, statistical analysis was done. The analysis shows in Graph 8,9 \&10 that the level of concentration of Suspended Particulate Matter (SPM) at all the locations SPM correlation values observed and it shows low degree of correlation $\left(0.0\right.$ to $\left.{ }_{-}^{+} 0.3\right)$ at Nal Stop range from -0.05 to -0.34 . And high degree of correlation observed at Swargate \& Pune. Maximum correlation observed with two wheelers. Table 5 shows correlation values at Swargate, Table 6 \& 7 shows correlation values at Nal Stop \& Pune respectively. Air quality SPM concentrations was observed to be more than $200 \mu \mathrm{g} / \mathrm{m}^{3}$ which is high compared to the standard reading $\left(140 \mu \mathrm{g} / \mathrm{m}^{3}\right)$ given by National Ambient Air Quality Standards (NAAQS) CPCB. Study shows that at Swargate site SPM concentrations range observed between $203 \mu \mathrm{g} / \mathrm{m}^{3}$ to $250 \mu \mathrm{g} / \mathrm{m}^{3}$, Nal Stop between $216 \mu \mathrm{g} / \mathrm{m}^{3}$ to $226 \mu \mathrm{g} / \mathrm{m}^{3}$, Pune between $211 \mu \mathrm{g} / \mathrm{m}^{3}$ to $238 \mu \mathrm{g} / \mathrm{m}^{3}$, maximum concentration of SPM observed in year 2009 at all the locations. This shows that there were external factors acting on it. Improved fuel quality, vehicle design can reduce the effect of SPM on environment. PM 10 emission inventory shows that there was $30.32 \mathrm{~kg} / \mathrm{km}$ is released in 2011 from vehicles. Petrol vehicles are contributing $69 \%$ of total emission.

RSPM was observed to be a low degree of correlation $\left(0\right.$ to $\left.{ }_{-}^{+} 0.3\right)$ at Swargate and Pune. However at Nal stop RSPM shows moderate degree of correlation $\left({ }_{-}^{+} 0.3\right.$ to $\left.{ }_{-}^{+} 0.7\right)$ with vehicles which shows a positive value maximum correlation found with bus. Level of concentration of Respirable Suspended Particulate Matter (RSPM) was observed to be more than $80 \mu \mathrm{g} / \mathrm{m} 3$ which is high compared to standard level $\left(60 \mu \mathrm{g} / \mathrm{m}^{3}\right)$ given by NAAQS by CPCB at all the locations. At Swargate RSPM concentration range between $80 \mu \mathrm{g} / \mathrm{m}^{3}$ to $92 \mu \mathrm{g} / \mathrm{m}^{3}$, at Nal Stop concentrations range was $80 \mu \mathrm{g} / \mathrm{m}^{3}$ to $88 \mu \mathrm{g} / \mathrm{m}^{3}$. Analysis shows that at Pune its ranging from $113 \mu \mathrm{g} / \mathrm{m}^{3}$ to $123 \mu \mathrm{g} / \mathrm{m}^{3}$. Which clearly indicates that all concentrations were above the standard level $\left(60 \mu \mathrm{g} / \mathrm{m}^{3}\right)$ given by NAAQS by CPCB, maximum concentration of RSPM is observed in 2009. RSPM has a very less correlation with vehicles. Air quality data shows RSPM level is above the standard level. It clearly signifies that external factors are leading to emission of RSPM than vehicles viz. road dust, construction activities, and industries. Among vehicles buses are contributing more amount of RSPM emission. However at Nal stop RSPM shows a strong correlation that may be because of more traffic congestion.

Correlation between NOx and vehicles also observed to be high degree of correlation which has range from 0.70 to 0.84 . Maximum correlation found with three wheelers and four wheelers. NOx concentrations range observed between $40 \mu \mathrm{g} / \mathrm{m}^{3}$ to $68 \mu \mathrm{g} / \mathrm{m}^{3}$, At Swargate concentrations range were $41 \mu \mathrm{g} / \mathrm{m}^{3}$ to $68 \mu \mathrm{g} / \mathrm{m}^{3}$, at Nal Stop $38 \mu \mathrm{g} / \mathrm{m}^{3}$ to $68 \mu \mathrm{g} / \mathrm{m}^{3}$, Pune range was between $42 \mu \mathrm{g} / \mathrm{m}^{3}$ to $64 \mu \mathrm{g} / \mathrm{m}^{3}$ maximum concentration were 
observed in 2011 at all the location and it was also above the standard level given by NAAQS. NOx Study shows that increasing vehicles contributes to increase in NOx emission. From emission inventory estimated that in 2011 NOx emission by vehicles was $824 \mathrm{~kg} / \mathrm{km}$ released and petrol vehicles contributing 89\%. Study also shows that petrol vehicles are major polluting than any other fuel. Air quality also shows that NOx concentrations were above the standard level in 2011

Analysis shows that correlation between $\mathrm{SO}_{2}$ and all vehicles (two wheeler, four wheeler, three wheeler and bus) observed high degree of correlation range from 0.7 to 1.0 correlation(r). Maximum correlation with $\mathrm{SO}_{2}$ and vehicle was found to be with three wheelers and four wheelers. In air quality $\mathrm{SO}_{2}$ concentrations were observed to be in range of $22 \mu \mathrm{g} / \mathrm{m}^{3}$ to $30 \mu \mathrm{g} / \mathrm{m}^{3}, \mathrm{SO}_{2}$ concentrations were found below standard level $\left(60 \mu \mathrm{g} / \mathrm{m}^{3}\right)$ given by NAAQS. At Swargate concentrations of $\mathrm{SO}_{2}$ observed between $22 \mu \mathrm{g} / \mathrm{m}^{3}$ to $30 \mu \mathrm{g} / \mathrm{m}^{3}$, at Nal Stop it was between $21 \mu \mathrm{g} / \mathrm{m}^{3}$ to $29 \mu \mathrm{g} / \mathrm{m}^{3}$, Pune shows $\mathrm{SO}_{2}$ concentrations between $20 \mu \mathrm{g} / \mathrm{m}^{3}$ to $30 \mu \mathrm{g} / \mathrm{m}^{3}$. This show as vehicles going on increasing there is increase in $\mathrm{SO}_{2}$ concentrations. Vehicles are one of the major sources of $\mathrm{SO}_{2}$ emission because of sulphur content in fuel, improper combustion. It is also observed that among the vehicle fuels petrol contributes more $\mathrm{SO}_{2}$ emission than other, but others are also present in fair quantity as number of petrol based vehicle was more. But the air quality shows the concentrations of $\mathrm{SO}_{2}$ is well below standard limits that may be because of the dispersion of gas in atmosphere.

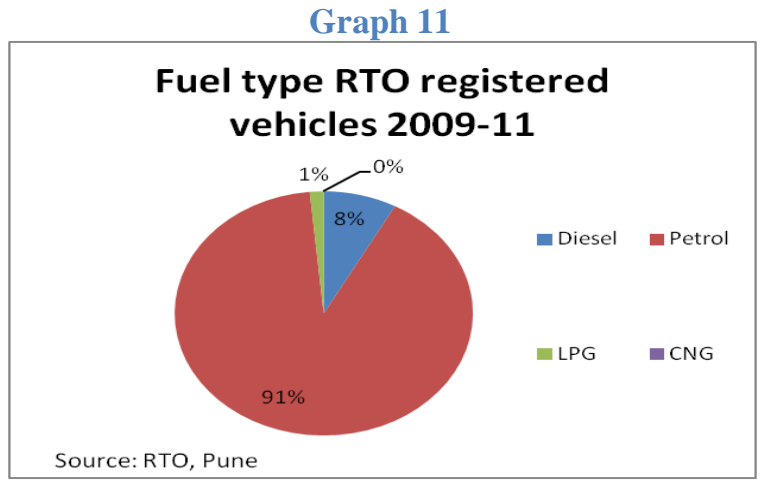

Graph 8 shows the fuel type segregation of Pune city (Source: RTO, Pune). It is observed that in 2009 and 2010 petrol vehicle contributed $91 \%$ vehicle growth while diesel contributes $8 \%$ and LPG 1\%. In 2011 petrol vehicles contributes $89 \%$, diesel $8 \%$, LPG $2 \%$ and CNG $1 \%$.

Graph 12

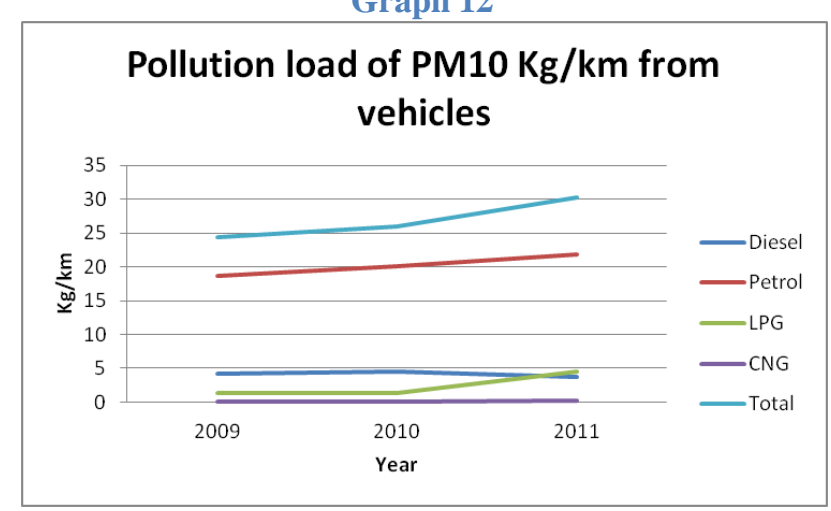

Graph 12 shows estimated pollution load of Particulate Matter (PM 10) emission from different vehicles in Pune City on the fuel basis total estimated emission $30.33 \mathrm{Kg} / \mathrm{km}$ in 2011. Petrol vehicles contribution was 69\%, diesel vehicle 19\% and LPG 12\% from 2009 to 2011. 


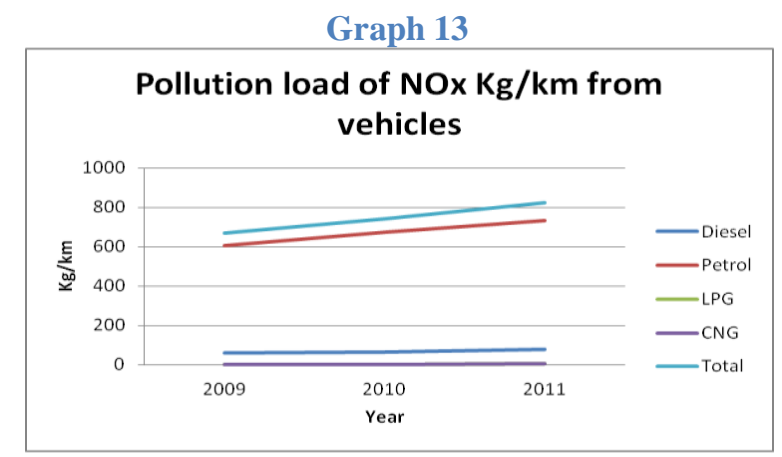

Graph 13 shows a NOx emission of from different vehicles on the fuel basis the maximum emission from petrol vehicles estimated that $91 \%$ from 2009 to 2011. In 2011 estimated emission from petrol vehicles observed $89 \%$

\section{Conclusions:}

1. At Swargate \& Nal Stop vehicles increased was calculated and compared with air quality it was observed that Air quality concentrations at Swargate was more than Nal stop, Although there were more vehicles at Nal Stop than Swargate that could be due to more traffic congestion, more public vehicles and more traffic signals at Swargate than Nal Stop.

2. Correlation studies showed as vehicles increased there was increase in $\mathrm{SO}_{2}$ and NOx levels. In 2011 it was observed that NOx concentrations were above standard level while $\mathrm{SO}_{2}$ concentrations were within standard level. At Swargate correlation between $\mathrm{SO}_{2}$ and vehicles shows maximum correlation with three wheelers and four wheelers i.e. 0.86, with two wheelers it was 0.81 and with bus it was 0.7. At $\mathrm{Nal}$ stop correlation was more than Swargate, maximum correlation with four wheelers and three wheeler that was 0.95 , two wheeler 0.92 and bus 0.89 . It shows that four wheeler and three wheelers have more impact on the $\mathrm{SO}_{2}$.

3. NOx concentration and correlation with vehicles showed that at Swargate correlation was more than that of at Nal Stop, maximum correlation was found with four wheelers i.e. $0.84 \& 0.8$ at Swargate and $\mathrm{Nal}$ Stop respectively. It shows that four wheeler and three wheelers have more impact on the $\mathrm{SO}_{2}$ and NOx. NOx emission inventory shows vehicle contributes $94.63 \%$ of emissions than any other sources. (Source: Emission inventory report, ARAI)

4. At Nal Stop it was seen that correlation between RSPM and vehicles have maximum with buses i.e. 0.7 followed by 0.62 for two wheelers, 0.56 for four wheelers and 0.5 for three wheelers which indicates that buses were have more impact on RSPM. This could be due to diesel fuel, improper combustion which leads to release of RSPM. PM10 emission inventory shows 53\% emission from vehicles combustion of fuel without considering road side dust than any other sources.(Source: Emission inventory report, ARAI)

5. There is dramatic growth in personal vehicles which pushing load on road network and causing traffic congestion and road accidents. Personal vehicles are contributing $90 \%$ of total vehicles registered. The average occupancy of two wheelers is 1 and four wheelers is 1.3. Pune has narrow roads in core parts of the city. Due to this fact and lack of public transport, personal mobility using a bike. The same is reflected in exponential vehicle growth and high two wheeler numbers.

6. It is observed that petrol vehicles are contributing more pollution that any other fuel vehicles. And there are $91 \%$ petrol vehicle registered from 2009 to 2011 while diesel vehicles were $8 \%$.

7. It is observed that there was increase in CNG vehicles in 2010 to 2011 from 445 to 12858 vehicles. This also increased pollution load from $5 \mathrm{gm} / \mathrm{km}$ to $188 \mathrm{gm} / \mathrm{km}$ PM10 emission and from $268 \mathrm{gm} / \mathrm{km}$ to $6550 \mathrm{gm} / \mathrm{km}$ NOx emission.

8. Vehicles have been identified as the major source of air pollutants in metropolitan cities. The reasons for high rates of vehicle emissions include poor fuel quality, high vehicular density, the large number of old vehicles, inadequate I\&M system, poor vehicle design, fuel adulteration, improper traffic management, and inadequate mass transport systems. 
Assessment of Traffic Related Air Pollution and Ambient Air Quality of Metropolitan Cities (Case Study of $\underline{\text { Pune City) }}$

\section{References:}

1. Traffic Forecast for the Proposed Metro Rail Project in Pune Metropolitan Area Report on Methodology and Data, Transportation Systems Engineering Group Civil Engineering Department Indian Institute of Technology Bombay Powai, Mumbai400076 March 2008

2. Air Quality Monitoring and Emission Source Apportionment Study for Pune [ARAI/IOCL-AQM/R-12/2009-10] The Automotive Research Association of India, Pune.

3. 12 INDIAN CITIES: Transport Indicators, Centre for sustainable transport India

4. A review of traffic-related air pollution exposure assessment studies in the developing world. Xianglu Han, Luke P. Naeher* The University of Georgia, College of Public Health, Department of Environmental Health Science, 150 EHS Building, Athens, GA 30602, USA Received 3 February 2005; accepted 10 May 2005. Available online 6 July 2005

5. Assessment of ambient air quality in urban centres of Haryana (India) in relation to different anthropogenic activities and health risks. C. P. Kaushik*, Ravindra Khaiwal\#, Krishan Yadav, Surender Mehta and A. K. Haritash, Department of Environmental Science \& Engineering, Guru Jambheshwar University, Hisar-125001, Haryana, India.

6. Assessment of exposure to traffic related air pollution of children attending schools near motorways. Nicole A.H. Janssen, Patricia H.N. van Vliet, Franc!ee Aarts, Hendrik Harssema, Bert Brunekreef* Environmental and Occupational Health Group, Utrecht University, P.O. Box 80 176, 3508 TD Utrecht, Netherlands (Received19 April 2000; received in revised form 2 February 2001; accepted 10 February 2001)

7. Transport and Urban Air Pollution in India. Madhav G. Badami, School of Urban Planning and McGill School of Environment, McGill University, Macdonald-Harrington Building, 815 Sherbrooke Street West Montreal, Quebec, Canada H3A 2K6. DOI: 10.1007/s00267-004-0106-x

8. Climate Impacts of Air Quality Policy: Switching to a Natural Gas-Fueled Public Transportation System in New Delhi. Conorc. O. Reynolds $\dagger$, Milind Kandlikar*, + Institute for Resources, Environment and Sustainability, University of British Columbia, 2202 Main Mall, Vancouver, British Columbia, V6T 1Z4, Canada, Institute of Asian Research, University of British Columbia, 1855 West Mall, Vancouver, British Columbia, V6T 1Z2, Canada, and Liu Institute for Global Issues, University of British Columbia, 6476 NW Marine Drive Vancouver, British Columbia, V6T 1Z2, Canada received November 13, 2007 Revised manuscript receivedMarch 20, 2008. Accepted May 27, 2008.

9. Development of real-world driving cycle: Case study of Pune, India Sanghpriya H. Kamble a, Tom V. Mathew b,*, G.K. Sharma a. Central Institute of Road Transport, Pune, India b. Department of Civil Engineering, Indian Institute of Technology Bombay, Powai, Mumbai, Maharastra 400 076, India.

10. Trends in Transport, Air Quality, and $\mathrm{CO} 2$ Emissions in 12 Indian Cities. Centre for sustainable transport India

11. Estimates of emission and deposition of reactive nitrogenous species for India. C. Sharma ${ }^{1}$, M. K. Tiwari ${ }^{1}$ and H. Pathak ${ }^{2}$, National physical laboratory, New Delhi, 110 012, India, International Rice Research Institute-India, NASC Complex, Pusa, New Delhi 110012, India.

12. EVALUATION OF DEVELOPMENT SCENARIOS TOWARDS SUSTAINABLE URBAN TRANSPORTATION: A CASESTUDY OF PUNE. Sandhya Nadimpalli, Balakrishna Kannemadugu, Krishna Rao.

13. AMBIENT AIR QUALITY IN METROPOLITAN CITIES (A CASE STUDY OF METROPOLITAN PUNE). Prof. M. R. Gidde, Bharati Vidyapeeth University College of Engineering, Pune - 411043

14. Impact of rapid urban growth on heat and moisture islands in Pune City, India. Vrishali Deosthali, Department of Geography, University of Pune, Karve Road, 40/12 Deep-Vishwa paud Fata, Pune 411007, India Received 20 July 1998. Accepted 22 July 1999. Available online 18 April 2000.

15. Urban Air Pollution And its Influence on Health in India. Dr. Dewaram A. Nagdeve, International Institute for Population Sciences, Mumbai 400 088, Published in IIPS Mumbai, ENVIS center, Volume 1, No. 3, September 2004

16. Slow Murder: The Insidious Link between Vehicular Pollution - Public Health - Climate - and Urban Poor in India. Anumita Roychowdhury, Centre for Science and Environment ${ }^{l}$ Background Paper for Conference on the "The Environments of the Poor", Asian Development Bank, 24-26 Nov 2010, New Delhi ${ }^{2}$

17. TRANSPORT AND ENVIRONMENT SIMULATION FOR BANGALORE, PUNE AND HYDERABAD, S. Rama Krishna, C. Ravi Kumar Reddy, Members of Faculty, Central Institute of Road Transport (CIRT), Pune, India

18. Emissions from India's transport sector: Statewise synthesis. T.V. Ramachandra ${ }^{\mathrm{a}, \mathrm{b},{ }^{*},}$, Shwetmala a a Energy Research Group (CES), Centre for Ecological Sciences, Indian Institute of Science, Bangalore, Karnataka 560 012, India b Centre for Infrastructure, Transport and Urban Planning (CiSTUP), Indian Institute of Science, Bangalore 560 012, India

19. Unravelling myths about subsidies in urban transport: Case study of Pune, Ashok Sreenivas, Girish Sant Prayas Energy Group,

20. Health Aspects of Air Pollution with Particulate Matter, Ozone and Nitrogen Dioxide, Bonn, Germany 13-15 January 2003 
Assessment of Traffic Related Air Pollution and Ambient Air Quality of Metropolitan Cities (Case Study of Pune City)

\section{ANNEXURE:}

National Ambient Air Quality Standards:

\begin{tabular}{|c|c|c|c|c|}
\hline \multirow{2}{*}{ Pollutants } & \multirow{2}{*}{$\begin{array}{c}\text { Time-weighted } \\
\text { Average }\end{array}$} & \multicolumn{3}{|c|}{ Concentration in ambient air } \\
\hline & & Industrial Areas & $\begin{array}{l}\text { Residential, Rural \& } \\
\text { other areas }\end{array}$ & Sensitive Areas \\
\hline \multirow{2}{*}{$\begin{array}{l}\text { Sulphur Dioxide } \\
\left(\mathrm{SO}_{2}\right)\end{array}$} & Annual Average & $80 \mu \mathrm{g} / \mathrm{m}^{3}$ & $60 \mu \mathrm{g} / \mathrm{m}^{3}$ & $15 \mu \mathrm{g} / \mathrm{m}^{3}$ \\
\hline & 24 hours & $120 \mu \mathrm{g} / \mathrm{m}^{3}$ & $80 \mu \mathrm{g} / \mathrm{m}^{3}$ & $30 \mu \mathrm{g} / \mathrm{m}^{3}$ \\
\hline \multirow{2}{*}{$\begin{array}{l}\text { Oxides of Nitrogen } \\
\text { (NOx) }\end{array}$} & Annual Average & $80 \mu \mathrm{g} / \mathrm{m}^{3}$ & $60 \mu \mathrm{g} / \mathrm{m}^{3}$ & $15 \mu \mathrm{g} / \mathrm{m}^{3}$ \\
\hline & 24 hours & $120 \mu \mathrm{g} / \mathrm{m}^{3}$ & $80 \mu \mathrm{g} / \mathrm{m}^{3}$ & $30 \mu \mathrm{g} / \mathrm{m}^{3}$ \\
\hline \multirow{2}{*}{$\begin{array}{l}\text { Suspended } \\
\text { Particulate } \\
\text { Matter(SPM) }\end{array}$} & Annual Average & $360 \mu \mathrm{g} / \mathrm{m}^{3}$ & $140 \mu \mathrm{g} / \mathrm{m}^{3}$ & $70 \mu \mathrm{g} / \mathrm{m}^{3}$ \\
\hline & 24 hours & $500 \mu \mathrm{g} / \mathrm{m}^{3}$ & $200 \mu \mathrm{g} / \mathrm{m}^{3}$ & $100 \mu \mathrm{g} / \mathrm{m}^{3}$ \\
\hline \multirow{2}{*}{$\begin{array}{l}\text { Respirable } \\
\text { Particulate } \\
\text { Matter(RPM) }\end{array}$} & Annual Average & $120 \mu \mathrm{g} / \mathrm{m}^{3}$ & $60 \mu \mathrm{g} / \mathrm{m}^{3}$ & $50 \mu \mathrm{g} / \mathrm{m}^{3}$ \\
\hline & 24 hours & $150 \mu \mathrm{g} / \mathrm{m}^{3}$ & $100 \mu \mathrm{g} / \mathrm{m}^{3}$ & $75 \mu \mathrm{g} / \mathrm{m}^{3}$ \\
\hline
\end{tabular}

Emission Inventory by ARAI

\begin{tabular}{|c|c|c|c|}
\hline \multicolumn{4}{|c|}{ Emission Inventory } \\
\hline & 2006-2010 & PM & Nox \\
\hline \multirow[t]{2}{*}{ 2-Wheeler } & Scooter $4 \mathrm{~S}$ & 0.015 & 0.25 \\
\hline & Motorcycle & 0.013 & 0.5 \\
\hline \multirow[t]{4}{*}{ Autorikshaw } & 3-Wheeler CNG 4S & 0.015 & 0.5 \\
\hline & 3-Wheeler Petrol 2S & 0.012 & 0.2 \\
\hline & 3-Wheeler LPG 2S & 0.13 & 0.04 \\
\hline & 3-Wheeler Diesel & 0.091 & 0.51 \\
\hline \multirow[t]{5}{*}{ 4-Wheeler } & 4-Wheeler-Petrol & 0.002 & 0.09 \\
\hline & 4-Wheeler-Diesel & 0.015 & 0.28 \\
\hline & 4-Wheeler-LPG & 0.002 & 0.2 \\
\hline & 4-Wheeler-CNG & 0.006 & 0.74 \\
\hline & LCVs 4wheeler GC & 0.475 & 2.12 \\
\hline Trucks and MAV & Large Trucks+MAV & 0.42 & 8.63 \\
\hline \multirow[t]{2}{*}{ BUS } & Buses-Diesel & 0.3 & 6.53 \\
\hline & Buses-CNG & 0 & 6.21 \\
\hline
\end{tabular}

